\title{
Developing Powtoon-Based Video Learning Media for Five Grade Students of Elementary School
}

\author{
Yanuari Dwi Puspitarini \\ Educational Technology \\ Sebelas Maret University \\ Surakarta, Indonesia \\ tp11010.yanuaridwi@gmail.com
}

\author{
Muhammad Akhyar \\ Educational Technology \\ Sebelas Maret University \\ Surakarta, Indonesia \\ makhaliya@yahoo.com
}

\section{Djono}

Educational Technology

Sebelas Maret University

Surakarta, Indonesia

djono_sk@yahoo.com

\begin{abstract}
The role of the media cannot be separated from the learning process. Along with the development of science and technology, teachers can use it in the learning process. The development of powtoon-based video learning media in social studies subjects is motivated by the lack of instructional media used by teachers in learning activities. This study aims to: 1) develop video learning media on IPS subjects for five elementary school classes, and 2) determine the feasibility of learning video media based on experts and students. This study uses a type of research and development ( $R$ \& $D$ ) developed using the ASSURE model. The steps of this study are 1) Analysing the characteristics of the learner, 2) Stating objectives, 3) Selecting Methods, media, and materials 4) Utilising materials 5) Requiring the participation of learners, and 6) Evaluation and revision. This study was conducted in four of the six stages of ASSURE. The results of research are 1) the media developed in the form of the powtoon-based video learning device. 2 ) the result of validation of media experts developed is 4.20 with good category, 3) the result of material validation on media is 4.19 with good category, 4) validation of product test result one-to-one is 4.07 with a very good category, small group trials 4.32 with a very good category; and field trials at 4.19 with a good category. Thus, the powtoonbased video learning media developed is feasible to be used as a learning medium.
\end{abstract}

Keywords_ — instructional media; social studies; powtoon app

\section{INTRODUCTION}

Education today is a staple for a human being. Human education can advance life and nation. Therefore, the current education system continues to be developed in order to produce qualified graduates. Improving the quality of education can be done through various aspects, ranging from aspects of human resources, facilities, materials, methods, and no less important is the learning process. Learning is a combination that consists of several things, namely human, means, and procedures where all parties influence each other in achieving the goal [1]

One aspect that cannot be separated from the learning process is the use of media. Learning media is anything that can be used to convey a message so as to stimulate students' feelings, thoughts, willingness, and attention, while encouraging the learning process [2]. Learning media commonly used in the learning process include modules, textbooks, student worksheets, and BSE (Electronic School Book).

The development of science and technology (Science and Technology) is currently on a rapid pace and also the development affects of the world of education. One of the influences of technology in the world of education is its use in the learning process as a medium of learning. The use of technology in the current learning process is very likely to be used because most schools have facilitated tools to support the use of technology in the learning process. Utilisation of technology as a medium of learning can serve as a means to overcome the limitations that exist in the learning process, so as to maximise the learning objectives.

The success of the learning process can be seen from the changes in behaviour and student learning outcomes. The success of the learning process or the achievement of learning cannot be separated from the learning motivation that is owned by the students. MC. Donald [1] mentions "motivation is an energy change within the person characterised by affective arousal and anticipatory goal reaction". This learning motivation will provide encouragement for students to follow the learning process, implemented to increase the expected learning results. This is in accordance with research conducted by Kusni [3] which states that the increase in learning motivation is followed by improved learning achievement.

Learning media can be used to overcome the limitations in the delivery of materials, learning media can also be used as a means to motivate students in the learning process. This is in accordance with the results of research conducted by Tina Heafner [4], which states "the use of technology in social studies as a means to motivate students by tools that improve students' self-efficacy and self-worth ". 
In line with Heafner, research on the use of video media in learning is also done by Choi and Johnson [5]. The study states that "There is a significant difference in learners' motivation in terms of attention between video-based instruction and traditional text-based instruction. In addition, students report that video-based instruction is more memorable than traditional text-based instruction. This research implies that video contextbased in the online course has the potential to improve retention and motivation of learners. The results of this study can be concluded that there are significant differences in student learning motivation when learning to use video media.

The results of interviews and observations conducted in the process of learning in the fifth grade of elementary school 2 Arenan and elementary school 3 Cipawon obtained the following information: 1) media used in the delivery of materials in the classroom are text books, drawings, student worksheets, and BSE (Electronic School Book); (2) when the material is delivered in the form of memorising material, the teacher uses textbooks as media; 3) the students are less interested in memorising material such as social studies subjects and quickly get bored with the delivery of the material using textbooks; 4) the material with the lecture method also bore the students quickly; and 5) student motivation is higher when the material is taught using props and media as a support tool in learning.

On the basis of the results of interviews and preliminary observations above, we will be conducting research in the form of learning media development using learning videos for fifth graders of the elementary school on social studies. Social studies are one of the areas taught at the primary school level. According to Trianto [6], social studies is an integration of various branches of social sciences, such as sociology, history, geography, economics, politics, law, and culture. The class' social studies learning tends to use the expository approach because of the lack of media that can be used to deliver the material. As a result of using this approach, the knowledge of the social studies concept obtained by students is only memorising the material. So that needed the media that can be exploited to convey social studies material to be delivered in diverse methods.

Video media is selected because it not only displays text, but also digitally packaged images and sounds. Daryanto [7] mentioned that the video provides a new way of learning because of the characteristics of video technology that provide moving images and sounds in the media. Media that has image and sound elements (sight and hearing) will increase the retention rate (memory and memory) of students on the subject matter delivered via video.

The application used to create instructional media in this research is powtoon. Powtoon is a software used to create exposures that have very interesting animated features including handwritten animations, animated cartoons, and more lively transition effects, as well as easy timeline settings (www.powtoon.com). Powtoon can create animated presentation videos to explain course material, business, and more.
The purpose of this research is to develop instructional media in the form of instructional video on social studies of a fifth grade class of elementary school. In addition to developing video learning media, this research is also to determine the feasibility of Powtoon-based learning videos based on the assessment of material experts, media experts, and user opinions (students).

The result of this research is product specification in the form of powtoon-based learning video on social studies fifth grade of elementary school. The results of this study are one of the alternative learning media that is expected to reduce the limitations in the delivery of materials and improve students' learning motivation.

The benefits of this research are expected to add a reference in the learning process by using technology. This media can also be used when teachers cannot attend classes

\section{RESEARCH METHODS}

The development model used in this study is ASSURE developed by Smaldino, Lowther, and Russel. The stages of this study are 1) Analysing the learner characteristics, 2) Stating objectives, 3) Selecting Methods, media, and materials 4) Utilising materials 5) Requiring the participation of learners and 6) Evaluating and revising. This study was conducted in four of the six stages of ASSURE.

The first stage in this study is the analysis. This stage is a preliminary study consisting of interview and observation activities in the learning process. This stage of analysis aims to determine the needs and characteristics of students. Next is the stage of determining the learning objectives. The purpose of this learning is determined from the syllabus and the lesson plan of the learning materials to be delivered. The purpose of this lesson is to describe the competence of knowledge, attitudes, and skills that students will have after the learning process. Then, the third stage is to choose the methods, media and teaching materials that will be used in the learning process. At this stage determined media, methods, and teaching materials will be used in the learning process. The last is to utilise the teaching materials that will be used in the learning process. Prior to utilising the components in the third stage, the validation and testing of the products developed is required. Validation and testing aim to determine the feasibility of the product to be applied in the learning process. The validation of the product is done by the expert and the trials are done by the user.

Expert validation consists of material experts and media experts, while trials are conducted through one-on-one trials (3 student), small group trials (9 students), and field trials (20 students). Data obtained in expert validation and trial to the user is in the form of quantitative data from the validation questionnaire. The data analysis technique used is descriptive statistical analysis. The quantitative data obtained is then converted into qualitative data on a scale of 5 : 
TABLE I. CONVERION OF QUANTITATIVE DATA TO QUALITATIVE DATA [8]

\begin{tabular}{ccc}
\hline Score Interval & Value & Category \\
\hline $\mathrm{X}>4,21$ & 5 & Very good \\
\hline $3,40<\mathrm{X} \leq 4,21$ & 4 & Good \\
\hline $2,60<\mathrm{X} \leq 3,40$ & 3 & Enough \\
\hline $1,79<\mathrm{X} \leq 2,60$ & 2 & Less \\
\hline $\mathrm{X} \leq 1,79$ & 1 & Very less \\
\hline
\end{tabular}

\section{FINDING AND DISCUSSION}

The four stages are 1) Analysing the learner characteristics, 2) Stating objectives, 3) Selecting methods, media, and materials 4) Utilising materials.

\section{A. Analysing the learner characteristics}

In this first stage, needs and student characteristics are analysed. The Result of the requirement analysis and characteristic of student is obtained from the interview and observation done to teacher of the fifth grade in state elementary school of 2 Arenan and state elementary school 3 Cipawon.

The results of interviews and observations can be obtained by: 1) learning media used in the delivery of social studies materials in the form of textbooks, student worksheets, and drawings, 2) Submission of the learning materials using lecture methods, 3) students who get bored faster when material is delivered using only textbooks or, student worksheets that decrease motivation, 4) existing facilities in schools such as LCDs are not utilised optimally.

Based on the information obtained from interviews and observations, it can be concluded that the necessary media support the delivery of materials by utilising existing facilities. Utilisation of this facility aims to reduce the verbal efforts in the delivery of material and create a more varied learning to enhance student learning motivation.

\section{B. Stating objectives}

This second stage determines the purpose of learning. This learning objective is adapted to the syllabus and lesson plan on the material to be submitted. In this study, the material to be delivered through the media is the preparation of Indonesian independence and the basic formulation of the state. The purpose of studying this material is that students can appreciate the service and role of the struggle in preparing for Indonesian independence. More details can be seen in the table below:

TABLE II. DESCRIPTION SK, COMPETENCY STANDARDS, BASIC COMPETENCE , INDICATORS, AND LEARNING PURPOSES USED IN MEDIA FORMULATION

\begin{tabular}{ll}
\hline $\begin{array}{l}\text { Competency } \\
\text { Standards }\end{array}$ & $\begin{array}{l}\text { Appreciate the role of warrior and community } \\
\text { leaders in preparing and maintaining } \\
\text { Indonesia's independence }\end{array}$ \\
\hline Basic Competence & $\begin{array}{l}\text { Appreciate the services and role of the struggle } \\
\text { in preparing for Indonesian independence }\end{array}$ \\
\hline Indicator & $\begin{array}{l}\text { Describe some efforts in preparation for } \\
\text { independence } \\
\text { Describe the need for the basic formulation } \\
\text { of the state prior to independence }\end{array}$ \\
\hline
\end{tabular}

\begin{tabular}{lll}
\hline & Identify some figures in preparing for \\
& $\begin{array}{l}\text { independence } \\
\text { Demonstrate respect for the services of } \\
\text { leaders in preparing for independence }\end{array}$ \\
\hline Learning objectives & $\begin{array}{l}\text { Students can appreciate the services and role } \\
\text { of the struggle in preparing for Indonesian } \\
\text { independence }\end{array}$ \\
\hline
\end{tabular}

\section{Selecting methods, media, and materials}

At this stage, we choose the methods, media and teaching materials that will be used in the learning process. Selection of appropriate methods, media, and teaching materials is important because they will make the learning process more effective and efficient. Selection of methods, media, and teaching materials are tailored to the needs of the delivery of materials can be done in 3 ways by buying media or teaching materials, modifying existing media or teaching materials, or producing new media or teaching materials. In this study, the learning method that will be used is the method of discussion, media format is the development of new products in the form of video animation media, and teaching materials used are textbooks and student worksheets. Selection of media formats is tailored to the existing facilities in schools such as internet and LCD that support in the process of making and utilising the media.

After selecting the media format to be developed, the next step is to produce the media. Media production process is divided into 3 stages, namely:

- Pre-production. At this stage, the activities undertaken are the study of curriculum and the preparation of flowchart media. The purpose of this is to find out the curriculum and syllabus used. This flowchart contains the content of the video to be produced. Flowchart on this media can be seen in the chart below:

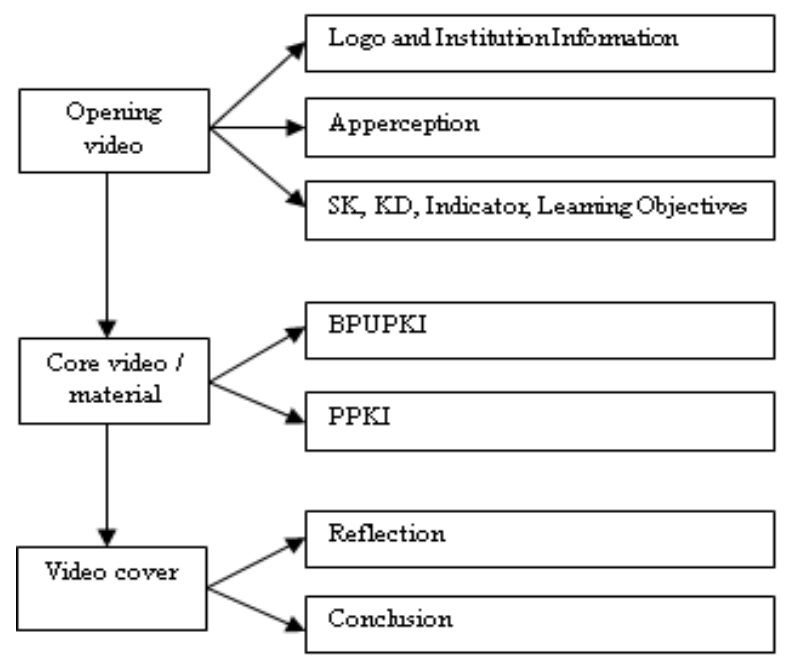

- Production. This production stage includes the application of flowcharts in powtoon applications, sound recording, and video editing. The output generated in this application is a video. This video can be opened on PC or laptop media. To create video media using this powtoon applications, one must be 
connected to the internet with a stable network. Some of the product views of this video medium are as follows:

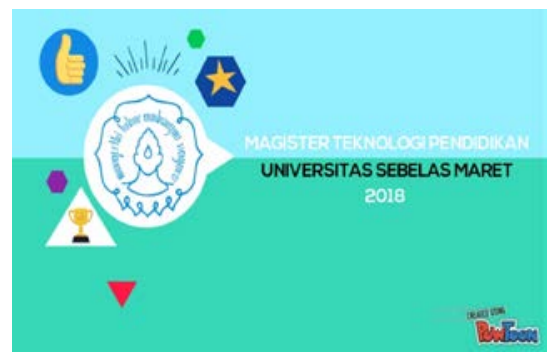

Fig. 1. Logo and Institution Information

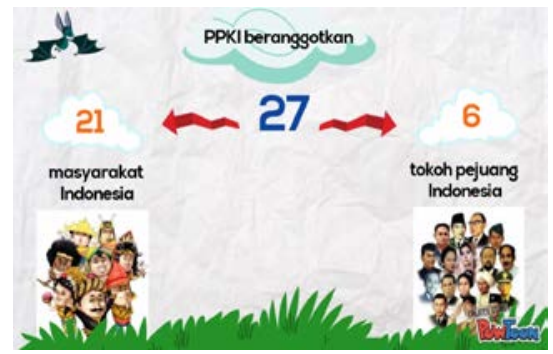

Fig. 2. Material

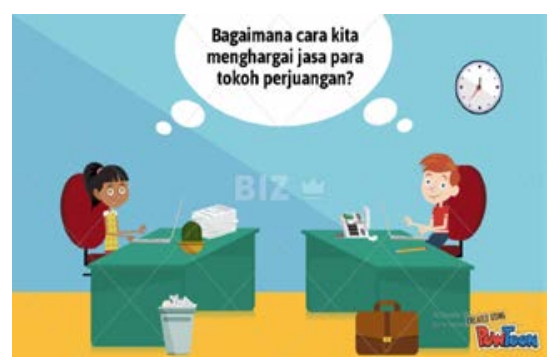

Fig. 3. Reflection

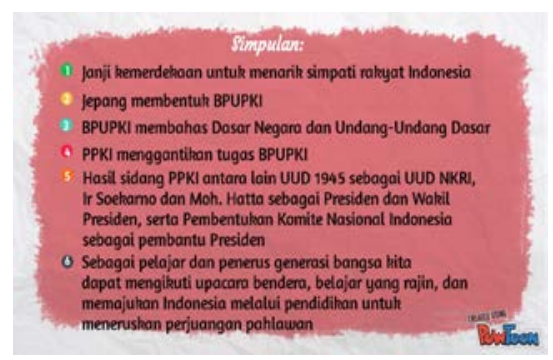

Fig. 4. Conclusion

- Post production. In the post-production stage is a review of the media that has been produced. This review is done by researchers on the results of the media that has been made. After a review by the researcher, the next step is validation performed by the expert and user validation through product trial.

\section{Utilising materials}

The next stage is to utilise methods, media and teaching materials that have been determined. Before using these three components, the developed medium needs to be validated and tested to ensure that the media developed is appropriate for use in the learning process. Validation was performed by material experts and media experts, while trials were conducted on 3 students on one-on-one trials, 9 students on small group trials and 20 students on field trials.

- Expert validation. Validation by experts is conducted by material experts and media experts. The material expert is someone who is considered to have mastered the material to be developed. The assessment of material aspects will be done by three material experts consisting of one lecturer and two fifth grade teachers. Assessments on material aspects include content feasibility, the feasibility of material presentation, and language feasibility. The results of the assessment of material aspects undertaken by the material experts can be seen in the following table.

TABLE III. RESULT OF MATERIAL EXPERT VALIDATION

\begin{tabular}{lccccc}
\hline \multicolumn{1}{c}{$\begin{array}{c}\text { Aspects of the } \\
\text { assessment }\end{array}$} & \multicolumn{3}{c}{ Material experts } & Average of & Catego \\
\cline { 2 - 4 } each aspect & I & II & III & ry \\
\hline Content & 3.37 & 4.46 & 4.30 & 4.04 & Good \\
\hline $\begin{array}{l}\text { Material } \\
\text { presentation }\end{array}$ & 5.00 & 4.50 & 4.50 & 4.67 & Good \\
\hline Language & 3.90 & 4.00 & 3.70 & 3.87 & Good \\
\hline $\begin{array}{l}\text { Average of each } \\
\text { expert }\end{array}$ & 4,09 & 4,32 & 4,17 & 4,19 & Good \\
\hline
\end{tabular}

Based on validation made by three material experts, it can be concluded that the average value of the validation results on aspects of the content is 4.04 with good category. The average value of the validation results on the aspects of the presentation of the material is 4.67 with good category, and the average value of the validation results on the language aspect is 3.87 with good category. So the average of all aspects of the material assessed is 4.19 with good category.

Media validation is done by media experts, who are competent in the media field. The media aspect assessment will be done by two media experts consisting of two lecturers. Assessment on media aspects include display, audio, ease of use, and media effectiveness. Media aspect assessment results by media experts can be seen in the following table.

TABLE IV. RESULT OF MEDIA EXPERT VALIDATION

\begin{tabular}{|c|c|c|c|c|}
\hline \multirow{2}{*}{$\begin{array}{l}\text { Aspects of the } \\
\text { assessment }\end{array}$} & \multicolumn{2}{|c|}{ Media experts } & \multirow{2}{*}{$\begin{array}{c}\text { Average of each } \\
\text { aspect }\end{array}$} & \multirow{2}{*}{$\begin{array}{c}\text { Catego } \\
\text { ry }\end{array}$} \\
\hline & $\mathrm{I}$ & II & & \\
\hline Display & 4.00 & 4.00 & 4.00 & Good \\
\hline Audio & 4.17 & 4.00 & 4.09 & Good \\
\hline Ease of use & 4.50 & 4.17 & 4.34 & $\begin{array}{l}\text { Very } \\
\text { good }\end{array}$ \\
\hline $\begin{array}{l}\text { Media } \\
\text { effectiveness. }\end{array}$ & 4.50 & 4.25 & 4.38 & $\begin{array}{l}\text { Very } \\
\text { good }\end{array}$ \\
\hline $\begin{array}{l}\text { Average of each } \\
\text { expert }\end{array}$ & 4.29 & 4.10 & 4.20 & Good \\
\hline
\end{tabular}

Based on validation made by two media experts, it can be concluded that the average value of the validation results on the aspect of the display is 4.00 with good category, the average value of the validation results on the audio aspect is 4.09 with good categories, the average of the validation results on the aspect of ease 
of use is 4.34 with very good category and the average value of the validation results on the aspect of the effectiveness of the media is 3.38 with very good category. So the average of all aspects of media assessed is 4, 20 with good category.

- User validation. Validation by a user is done by way of a product trial. Aspects assessed in product trials include display aspects, material aspects, and benefits aspects. Product trials were conducted through one-onone trials with 3 subjects, small group trials with 9 subjects, and field trials with 20 students. The results of the assessment of the user trial can be seen in the following table:

TABLE V. RESULT OF USER VALIDATION

\begin{tabular}{|c|c|c|c|c|c|c|}
\hline \multirow{2}{*}{ User trials } & \multirow{2}{*}{$\mathrm{N}$} & \multicolumn{3}{|c|}{$\begin{array}{c}\text { Aspects of the } \\
\text { assessment }\end{array}$} & \multirow{2}{*}{$\begin{array}{c}\text { Averag } \\
\text { e of } \\
\text { each } \\
\text { aspect }\end{array}$} & \multirow[t]{2}{*}{$\begin{array}{l}\text { Catego } \\
\text { ry }\end{array}$} \\
\hline & & $\begin{array}{c}\text { Displa } \\
\text { y }\end{array}$ & $\begin{array}{c}\text { Mate } \\
\text { rial }\end{array}$ & $\begin{array}{l}\text { Bene } \\
\text { fits }\end{array}$ & & \\
\hline $\begin{array}{l}\text { One-on-one } \\
\text { trials }\end{array}$ & 3 & 3.92 & 4.28 & 4.03 & 4.07 & $\begin{array}{l}\text { Very } \\
\text { Good }\end{array}$ \\
\hline $\begin{array}{ll}\text { Small } & \text { group } \\
\text { trials }\end{array}$ & 9 & 4.36 & 4.22 & 4.37 & 4.32 & $\begin{array}{l}\text { Very } \\
\text { Good }\end{array}$ \\
\hline Field trials & 20 & 4.18 & 4.16 & 4.24 & 4.19 & $\begin{array}{l}\text { Very } \\
\text { Good }\end{array}$ \\
\hline
\end{tabular}

User validation is done in three aspects: aspect of display, material aspect and benefit aspect. Based on the validation, the results of the three aspects of oneon-one trials (3 students) is 4.42 with very good category, the average of validation results from small group trials (9 students) was 4.32 with very good category, and the average result validation of field trials (20 students) was 4.19 with very good category.

Thus, the validation results of material experts, media experts, and user test results can be concluded that powtoon-based animated video media is appropriate for the learning process of social studies for a fifth grade elementary class.

\section{CONCLUSIONS AND SUGgESTIONS}

\section{A. Conclusions}

Based on the results of research and discussion, it can be concluded that the powtoon-based video media developed refers to the lack of learning media used by teachers in the delivery of materials to students. This medium was developed using ASSURE research procedures, which include: 1) Analysing the learner characteristics, 2) Stating objectives, 3) Selecting Methods, media, and materials 4) Utilising materials 5) Requiring the participation of learners, and 6) Evaluating and revising. In this research, the procedures are followed up to the fourth stage.

Validation results by media experts, materials experts, 3 students on a one-on-one trial, 9 students in small group trials, and 20 students in a field trial can conclude that powtoonbased video media developed is worthy of use as a supporting medium in the learning process. This is indicated by the results of the assessment that can be detailed as follows: 1) validation value by media experts 4.20 with good category, 2) validation value by material experts 4.19 with good category and 3 ) average value of one-on-one trials 4.07 with very good category, the average value of small group trials of 4.32 with very good category and the average value of field trials 4.19 with very good category.

\section{B. Suggestions}

Based on the research that has been carried out, some suggestions are as follows: 1) teachers need to develop learning methods, especially for the material memorisation and involving students in the learning process to increase students' interest, 2) teachers need to be more creative in delivering the material with utilising the facilities and infrastructure in the school, and 3) to improve students' learning motivation, teachers should be given the training to utilise existing technology such as creating varied and innovative learning media.

\section{REFERENCES}

[1] O. Hamalik, Kurikulum dan Pembelajaran [Curriculum and Learning]. Jakarta: Bumi Aksara, 2008.

[2] Y. Miarso, Menyemai Benih Teknologi Pendidikan [Sowing the Seeds of Education Technology]. Jakarta: Kencana Prenada Media Group, 2009.

[3] Kusni, "Peningkatan Motivasi dan Prestasi Belajar Pendidikan Agama Islam (PAI) Melalui Penggunaan Media Audio-Visual Siswa Kelas V SDN 2 Jomblang Kecamatan Jepon Kabupaten Blora Tahun Pelajaran 2011/2012 [Motivation and Studying Achivement Improvement of Islamic Education through the Usage of Audio-visual Media of 5th Grade Student of State Elementary School 2 Jomblang, Jepon Distrrict, Blora Regency, Study year 2011/2012]," Master's Thesis, Islamic Education Program, Walisongo State Islamic Institute, 2012.

[4] T. Heafner, "Using Technology to Motivate Students to Learn Social Studies,” Contemp. Iss. in Technol. and Teacher Edu., vol. 4, no. 1, pp. 42-53, 2004.

[5] H. J. Choi and S. D. Johnson, "The Effect of Context-Based Video Instruction on Learning and Motivation in Online Courses," Amer. J. of Dist. Edu., vol. 19, no. 1, pp. 215-227, 2010.

[6] Trianto, Model Pembelajaran Terpadu: Konsep, Strategi, dan Implentasinya dalam Kurikulum Tingkat Satuan Pendidikan (KTSP) [Integrated Learning Model: Concept, Strategy, and its Implementations in KTSP Curriculum]. Jakarta: Bumi Aksara, 2014.

[7] Daryanto, Media Pembelajaran: Perannya Sangat Penting dalam Mencapai Tujuan Pembelajaran [Learning Media: Its Role is Very Important in Reaching Learning Goals]. Yogyakarta: Gava Media, 2013.

[8] Y. S. Maharani, N. Suryani, and D. T. Ardianto, "Pengembangan Multimedia Pembelajaran Interaktif pada Mata Pelajaran Pengolahan Citra Digital di Sekolah Menengah Kejuruan Negeri 8 Semarang [Development of Multimedia Interactive Learning on Ditigal Image Subject at State Vocational High School 8 Semarang],” Prosiding Seminar Nasional Teknologi Pendidikan, 2017. 